\title{
Green Synthesis of Silver Nanoparticles Using Mandragora autumnalis; Its Characterization, Antioxidant and Antimicrobial Activities
}

\section{Yeșim DAĞLIOĞLU ${ }^{*}$ (D), Betül YILMAZ ÖZTÜRK²}

\author{
${ }^{1}$ Ordu University, Department of Molecular Biology and Genetics, Ordu \\ ${ }^{2}$ Eskişehir Osmangazi University Central Research Laboratory Application and Research Center (ARUM), \\ Eskişehir
}

Geliş / Received: 13/04/2021, Kabul / Accepted: 24/10/2021

\begin{abstract}
The green synthesis approach has benefits over traditional methods in silver nanoparticle synthesis that involve chemical agents interrelated environmental toxicity. For this reason, this approach has been preferred for the biosynthesis of silver nanoparticles (AgNPs). In addition, nanoparticles produced through plants are much more stable, large in size and shape range and can be biosynthesized in high amounts. Silver nanoparticles were synthesized from silver compound $\left(\mathrm{AgNO}_{3}\right)$ using bioactive compounds of Mandragora autumnalis as capping and reducing agents. Synthesized nanoparticles (Ma-AgNPs) were characterized by SEM, TEM, X-ray diffraction and UV-Vis absorption spectroscopy analyzes. X-ray diffraction analysis indicated that the nanoparticles had a crystalline structure. In SEM and TEM images, the spherical shaped and average size of Ma-AgNPs is 20-30 nm. The antioxidant activity was assessed by DPPH scavenging assay, in which the MaAgNPs indicated significant activity with respect to the standard antioxidant ascorbic acid. It showed a zone of inhibition against Gram positive (Bacillus subtilis, Staphylococcus aureus) and Gram negative (Escherichia coli and Pseudomonas aeruginosa) bacteria.
\end{abstract}

Keywords: antioxidant and antimicrobial activity, silver nanoparticles, Mandragora autumnalis, green synthesis

\section{Mandragora autumnalis Kullanılarak Gümüş Nanopartiküllerin Yeşil Sentezi; Karakterizasyonu, Antioksidan ve Antimikrobiyal Aktiviteleri}

\section{Öz}

Yeşil sentez yaklaşımı, gümüş nanopartikül sentezinde çevresel toksisite ile ilişkili kimyasal ajanları içeren geleneksel yöntemlere göre avantajlara sahiptir. Bu sebeple gümüş nanopartikülünün (AgNP) sentezlenmesinde bu yaklaşım tercih edilmiştir. Ayrıca, bitkiler tarafından üretilen nanopartiküller çok daha kararlı, boyut ve şekli aralığı fazla ve yüksek miktarda biyosentezi yapılabilmektedir. Gümüş nanopartikülleri, $\mathrm{AgNO}_{3}{ }^{\prime}$ ten, Mandragora autumnalis'ın biyoaktif bileşiklerini indirgeyici ve kapama ajanı olarak kullanarak başarılı bir şekilde sentezlendi. Sentez nanopartiküller (Ma-AgNP’ler), SEM, TEM, X-ışını kırınımı ve UV-vis absorpsiyon spektroskopisi analizleriyle karakterize edildi. X ışını kırınım analizi, nanopartiküllerin kristal yapıda olduğu görülmüştür. SEM ve TEM görüntülerinde Ma-AgNP'lerinin küresel şekilli ve ortalama boyutu 20-30 nm'dir. Ma-AgNP'leri, standart olarak Askorbik asit ile DPPH kullanılarak yüksek antioksidan aktivite gösterdiği kaydedilmiştir. Gram pozitif (Staphylococcus aureus, Bacillus subtilis) ve Gram negatif (Pseudomonas aeruginosa ve Escherichia coli) bakterilere karşı inhibisyon bölgesi göstermiştir.

Anahtar Kelimeler: Anahtar sözcükler küçük harflerle yazılmalı ve 3-5 anahtar sözcük bulunmalıdır. Anahtar sözcükler virgül (,) işareti ile birbirinden ayrılmalıdır. 


\section{Introduction}

In recent years, nanoparticles have become very popular, so toxicological evaluation of various nanoparticles has been made. (Dağlığlu, Y. 2018; Öztürk et al. 2018; Dağlığlu and Türkiş 2017a,b; Dağlığlu and Öztürk, B. 2016) . New researches have been begun on the biological synthesis of nanometals by using extracts obtained from plants and various parts of the plant. With these researches, nanoparticles (NPs) have been begun to be synthesized using fast and non-toxic methods (Thatoi et al. 2016; Rónavári et al. 2017). Many studies have reported the biosynthesis of metal nanoparticles with extracts of different parts of the plant and their possible applications. Medicines derived from parts of plant and their products are preferred because of their low cost and low side effects. Nanoparticles, which are synthesized from plant extracts, are now indicated as a possible alternative to antibiotics (Rai et al. 2012). Many different methods have been followed in the synthesis of nanoparticles. For example, chemical, physical or biological methods. Although physically and chemically synthesized metal nanoparticles are very preference, they have many disadvantages such as the use of toxic substances, environmentally unsafe, high temperature settings and high cost. The biosynthesis method using organic materials (algae, fungi, microorganisms and plants) to eliminate the disadvantages of physical and chemical methods has emerged as an environmentally friendly synthetic method (Özturk and Daglioglu, Y. 2021; Öztürk and Öztürk 2020; Öztürk and Öztürk, 2019; Alam et al. 2013; Dağlığlu and Öztürk 2019). In biosynthesis, the use of the plant extracts is effortless, fast, economical, non-toxic and applicable, so the plant extracts are easy and suitable for the manufacture of metal nanoparticles (Mehmood et al. 2014). Metal nanoparticles produced by plants have been indicated to be further stable than those produced by means of different organisms. Plants (especially plant extracts) can reduce metal ions quicker than fungus or bacteria. It has also been found that the plant extracts are more effective than using the living plants themselves to use an simple and reliably green method for the growth and manufacturation of well distributed nanoparticles (Bindhani and Panigrahi, 2015). Most of the nanoparticle synthesis methods are still in advancement and there are problems in the synthesis phase. Some of these problems are the stability, aggregation, crystal growth, size, morphology and size distribution of nanoparticles. Therefore, this type of research should be increased and developed.

Many metal nanoparticles ( $\mathrm{Ag}, \mathrm{Au}, \mathrm{Cu}, \mathrm{Fe}$ etc.) obtained by the green synthesis method have been reported (Öztürk et al. 2020; Annamalai et al. 2013; Jayarambabu et al. 2020; Mahmoodi et al. 2020). Silver nanoparticles (AgNPs) in particular have attracted considerable attention in different fields of science (Jana and Pal, 2007).

In this study, Mandragora autumnalis plant was chosen for silver nanoparticle synthesis. Mandragora autumnalis, known as mandrake, is a herbaceous perennial from the Solanaceae family (Francis, 2008). Historically, M. autumnalis has been used by Assyrians and Ancient Greeks as a medicinal herb and a potent narcotic. In the past, $M$. autumnalis fruits have often 
been used to treat fertility problems. It is highly toxic and dangerous due to its richness in atropine and scopolamine.

In this study, M. autumnalis was used as it has phytochemicals such as active alkaloids, tropanic alkaloids. AgNPs were synthesized using M. autumnalis root water extract. Later, this synthesis focused on the characterization, antioxidant and antimicrobial activity of the silver nanoparticle.

\section{Material and Methods}

\section{Plant materials}

Aqueous root extract of Mandragora autumnalis was used to synthesis silver nanoparticles (AgNPs) for its cost-effectiveness, ease of availability, and medicinal properties. The $M$. autumnalis was commercially obtained from herbalists. Subsequently, the surface of $M$. autumnalis was cleaned with running tap water to remove contaminated organic ingredients, then washed twice with distilled water at room temperature. After the synthesis process was completed, powder NPs were obtained by freeze-dried (Christ Alpha Plus).

\section{Preparation of aqueous extract}

In terms of toxicity, using water as a solvent is safer than other organic solvents. Aqueous extract was preferred for safe use of the silver nanoparticles obtained in later cell culture applications. $10 \mathrm{~g}$ fresh roots of M. autumnalis were ground and placed in $100 \mathrm{ml}$ of water and hold at room temperature for 72 hours. The extracts are then filtered in Whatman No 4 filter papers, the filtered extracts were stored at $-20^{\circ} \mathrm{C}$ for later experiments.

\section{AgNPs synthesis from extract and its characterization}

A previously stated methodology was used for the green synthesis of nanoparticles (Rónavári et al. 2017). The extract formed by the filtrate obtained after 72 hours of ground fresh roots in distilled water was diluted with different extract ratios (1:3) with distilled water to synthesize AgNPs. For the synthesis of silver nanoparticles, a concentration of filter sterilized silver nitrate $\left(\mathrm{AgNO}_{3}\right)$ under optimum conditions was used. Synthesis was first monitored by visual color change (transformation from light gray to dark brown color) in the reaction mixture, followed by spectral analysis (UV-Vis) E-S90-2D UV - Spectrophotometer. Thus, silver nanoparticles (Ma-AgNPs) was synthesized from M. autumnalis by green synthesis method.

Bio-reduction of silver ions during Ma-AgNP synthesis, after taking the UV-Vis reaction solution spectrum, the reaction solution was dried at $80^{\circ} \mathrm{C}$ for 6 hours to acquire purified MaAgNPs in dry form used for subsequent characterization. Surface morphology of Ma-AgNPs were evaluated from micrographs acquired from transmission electron microscopy (TEM). Optical properties of nanoparticles were examined by spectral analysis. The absorbance spectrum, particle size, zeta potential and electrical conductivity of Ma-AgNPs diluted in deionized water were measured with the Malvern-Zetasizer (Nano-Z590, United Kingdom). The temperature of the device was set at $25^{\circ} \mathrm{C}$ and the light scattering angle was set at $90^{\circ}$ during the measurements. Three consecutive measurements were made. The structure of Ma- 
AgNPs was defined by X-ray diffraction. Thus, an idea about the crystal structure of Ma-AgNPs was obtained. X-ray diffraction patterns of Ma-AgNPs were appliceted according to the definition of Wang (2000). After the samples were lyophilized, dried and powdered, they were used for XRD analysis.In scanning mode, X-ray diffraction patterns were recorded on an X'pert PRO PAN analytical instrument operated at $40 \mathrm{KV}$ and with $\mathrm{Cu} \mathrm{K} \propto$ radiation $(\lambda=1.5406 \AA)$ at a current of $30 \mathrm{~mA}$. Diffraction intensities were recorded from $10^{\circ}$ to $90^{\circ}$ at 2 theta angles. The software provided knowledge about the crystal feature of the nanoparticle.

\section{In vitro free radical scavenging activity}

Free radical scavenging ability of Ma-AgNP and Ma-Extract 1-diphenyl-2-picrylhydrazyl (DPPH) Brand-Williams et al. (1995) was determined by making minor changes in the method. Ma-AgNPs were sonicated for 20 minutes using a sonicator to prevent aggregation. Briefly, 1 $\mathrm{ml}$ of Ma-AgNP, Ma-extracts and ascorbic acid (standard) different concentrations (12.5, 25, 50 and $100 \mu \mathrm{g} / \mathrm{ml})$ were placed in tubes. Freshly prepared $1 \mathrm{~mL} \mathrm{DPPH}(1 \mathrm{mM})$ solution in 20 $\mu 1$ methanol was added onto it and the mixture was shaken vigorously. Then the prepared reaction mixture was incubated under shaking condition at room temperature in the dark for 30 minutes. Absorbance was measured at $517 \mathrm{~nm}$. Ascorbic acid was used as positive control (standard) and methanol as a blank. The change in absorbance (containing DPPH only) relative to the control is calculated as percent scavenging activity. The experiments were repeated three times and the percent scavenging activity was calculated using the following equation;

[(Absorbance control-Absorbance sample)/Absorbance control] $\times 100$

\section{Antimicrobial activity}

The antibacterial potential of M. autumnalis aqueous extract (Ma-extract) and AgNPs (MaAgNPs) synthesized from this extract were investigated in gram positive (Bacillus subtilis, Staphylococcus aureus) and gram negative bacteria (Escherichia coli and Pseudomonas aeruginosa) Saratale et al. (2017). Bacterial strains were obtained from Ordu University Microbiology Laboratory and grown overnight on nutrient agar medium as a fresh culture. The nutrient agar medium was prepared by dissolving $28 \mathrm{~g}$ of nutrient agar powder in $1000 \mathrm{~mL}$ distilled water and sterilizing in an autoclave at $121^{\circ} \mathrm{C}$. All sample used for antibacterial testing were sterilized. From the fresh culture, each bacterium was inoculated in $10 \mathrm{~mL}$ of distilled water by being dipped into a bacterial ring. From the inoculum, $1 \mathrm{~mL}$ of dilution was transferred to Petri plates, followed by a sufficient amount of liquid nutrient agar medium. The medium and the bacterial dilution were thoroughly mixed with soft agitation and then allowed to harden at room temperature. Filter paper discs $(6 \mathrm{~mm}$ ) were dipped in $100 \mu \mathrm{g} / \mathrm{mL} \mathrm{Ma}-\mathrm{AgNP}$ and MaExtract. Discs prepared in this way were placed on the coated agar in their labeled position. For reference, the commercially available antibiotic, penicillin, was used as a positive control. Plates containing the bacterial culture were incubated for 24 hours at $37^{\circ} \mathrm{C}$ and the zone of inhibition around each disc was measured in millimeters $(\mathrm{mm})$ using the scale. The experiment was performed in triplicate and the antibacterial activity, with its mean and standard deviation, is presented in Table 2 . 


\section{Resarch Findings}

\section{Characterization of Ma-AgNPs}

\section{UV-Vis spektrofotometre}

Biodegradation of Ma-AgNPs by green synthesis was observed by taking $3 \mathrm{ml}$ samples by scanning silver ions and silver nanoparticles for optimization purposes. Absorption measurements were made with a spectrophotometer between 190 and $1100 \mathrm{~nm}$. The present study indicated that when the M. autumnalis aqueous extract was exposed to silver ions $\left(\mathrm{AgNO}_{3}\right)$, the color of the extract changed from gray to brown, and when the control group $M$. autumnalis was compared, $\mathrm{Ag}^{+}$ion was biologically transformed to $\mathrm{Ag}^{0}$. Discoloration started within the first 24 hours during exposure. Spectrophotometric measure revealed a sharp absorption band at $435 \mathrm{~nm}$ for Ma-AgNPs (Figure 1). A characteristic absorption band in the visible regions (390-

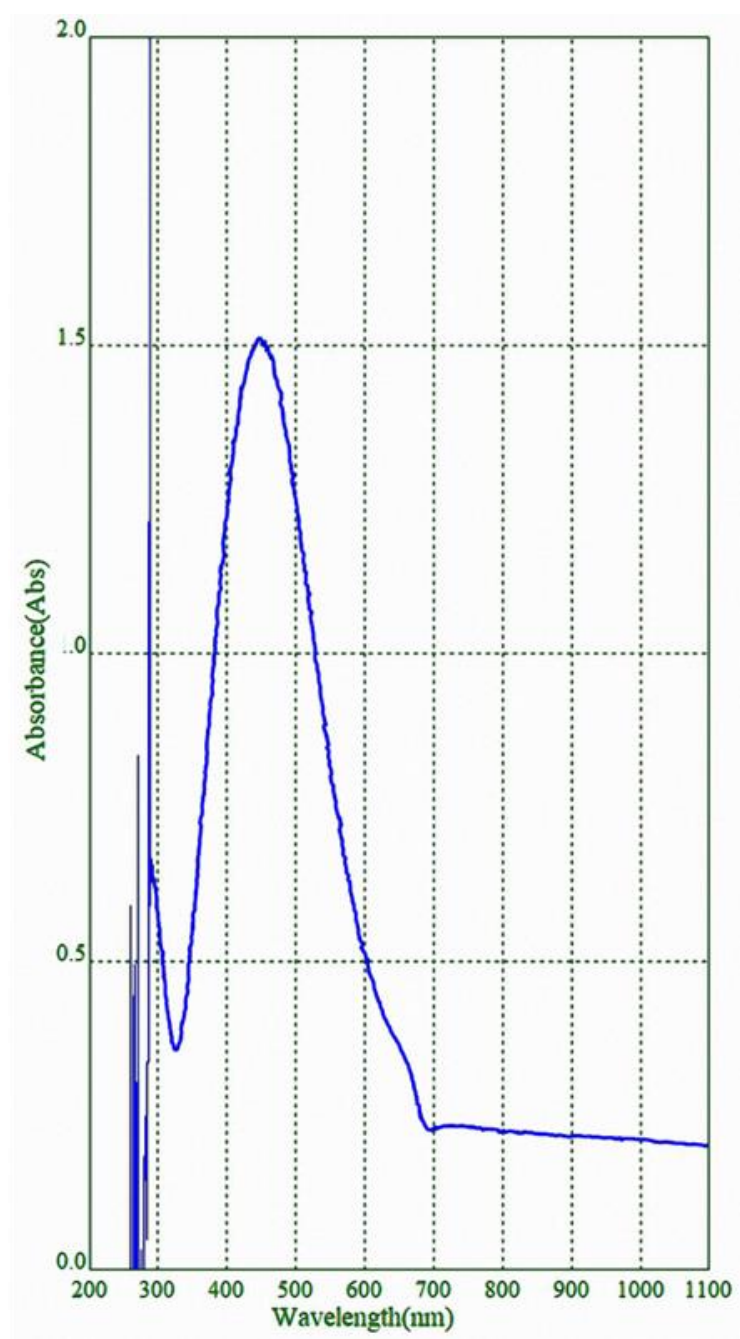

Figure 1. UV-Vis absorption spectra of Ma-AgNPs

$500 \mathrm{~nm}$ ) is evidence of the presence of surface plasmon resonance (SPR) of AgNPs (Muthukrishnan et al. 2015; Kanipandian et al. 2014). A single SPR band in the 300 to $700 \mathrm{~nm}$ 
range corresponds to round-shaped nanoparticles, while multiple SPR bands are related to the anisotropy of SNPs (Yousaf et al. 2020). In our study, the SPR band for AgNPs reveals the spherical shape of SNPs (Sands, 1993). During this study, especially the $\mathrm{pH}$, temperature and extract amount were optimized. The direction of the study was determined after this optimization. The final version was used for other characterization steps.

\section{DLS and Zeta Potential measurements of Ma-AgNPs}

In Figure 2A DLS analysis, it was determined that the Ma-AgNPs synthesized by the green synthesis method had a uniform particle size. In addition, the PDI (polydispersity index) value of Ma-AgNPs is between 0.237. The PDI value between 0.1-0.25 means monodispersity (narrow dispersion), and above 0.5 means wide dispersion due to large particles and aggregate formation. (Nidhin vd., 2008; Gürsoy vd., 2021). The potential $\mathrm{Z}$ value of $-25.3 \mathrm{mV}$ of MaAgNPs indicates that they are composed of stable and negatively charged particles. (Figure $2 \mathrm{~B}$ ).
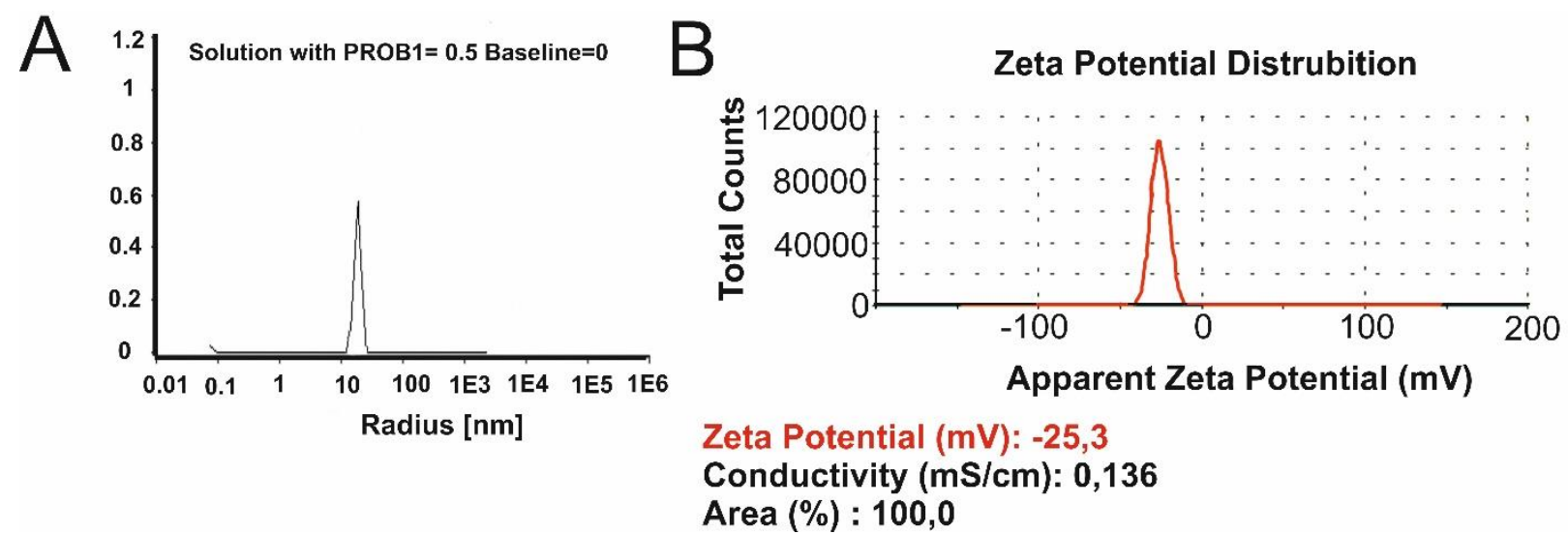

Figure 2. Zeta potential and conductivity diagram (A), Dynamic light scattering diagram for size distribution of Ma-AgNPs (B).

\section{SEM AND TEM analysis of Ma-AgNPs}

SEM images of Ma-AgNPs and their average sizes are shown in Figure 3. According to these images, AgNPs exhibited spherical shapes. The particles are unevenly distrubuted and have an average size of 20-30 $\mathrm{nm}$. Morphology and size of Ma-AgNPs were analyzed by transmission electron microscopy (TEM) to obtain more detailed images. It showed the presence of spherical Ma-AgNPs in TEM micrographs as well as in SEM images. Spherical Ma-AgNP images of 20$30 \mathrm{~nm}$ were obtained in these micrographs (Figure 3).

\section{XRD analysis of Ma-AgNPs}

XRD patterns of silver nanoparticles synthesized using M. autumnalis are shown in Figure 4. Accordingly, the dense diffraction peak of $2 \theta$ from the lattice plane of the face-centered cubic 
/ face-central cubic (fcc) silver ( $\left(\begin{array}{lll}1 & 1 & 1\end{array}\right)$ indicates that the particles are made of pure silver. The obtained XRD pattern shows that the silver nanoparticles are crystalline in nature. Three additional broadbands at $47.84^{\circ}(2 \theta), 61.71^{\circ}(2 \theta)$ and $73.95^{\circ}(2 \theta)$ correspond to the silver planes (2 000$),\left(\begin{array}{lll}2 & 2 & 0\end{array}\right)$ and $\left(\begin{array}{lll}3 & 1 & 1\end{array}\right)$ respectively. Other spurious diffractions result from impurities of organic matter. In the spectrum obtained, Bragg peak position and intensities were compared with standard JCPDS files. As a result, the XRD pattern of AgNPs confirmed the face-centered crystal structure as shown in Figure 4. All peaks matched FCC symmetry silver and JCPDS No. It is consistent with 00-004-0783 and the crystal structure of the nanoparticles was determined as cubic.

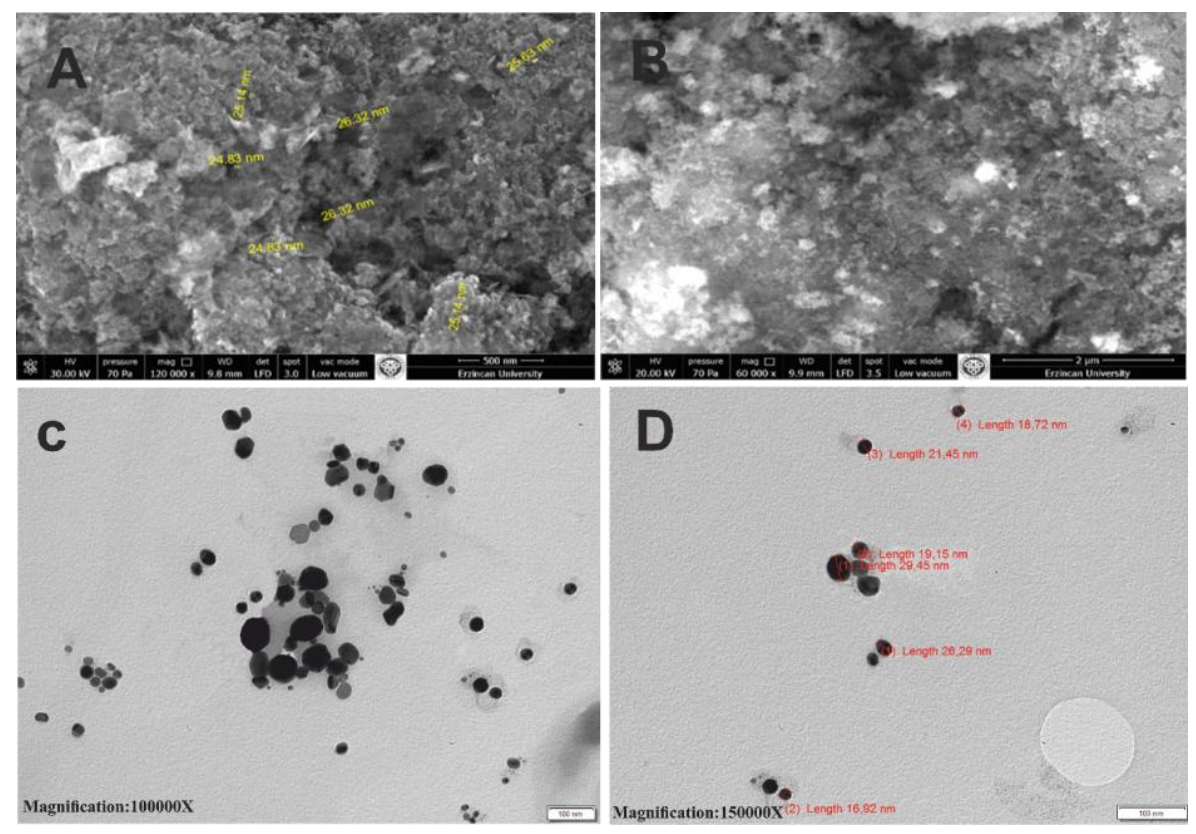

Figure 3. SEM micrographs of biosynthesized Ma-AgNPs using the root extract of $M$. autumnalis, A. (500 nm scale), B. ( $2 \mu$ scale). TEM micrographs of biosynthesized Ma-AgNPs using the root extract of $M$. autumnalis, C ve D. (100 nm scale). 


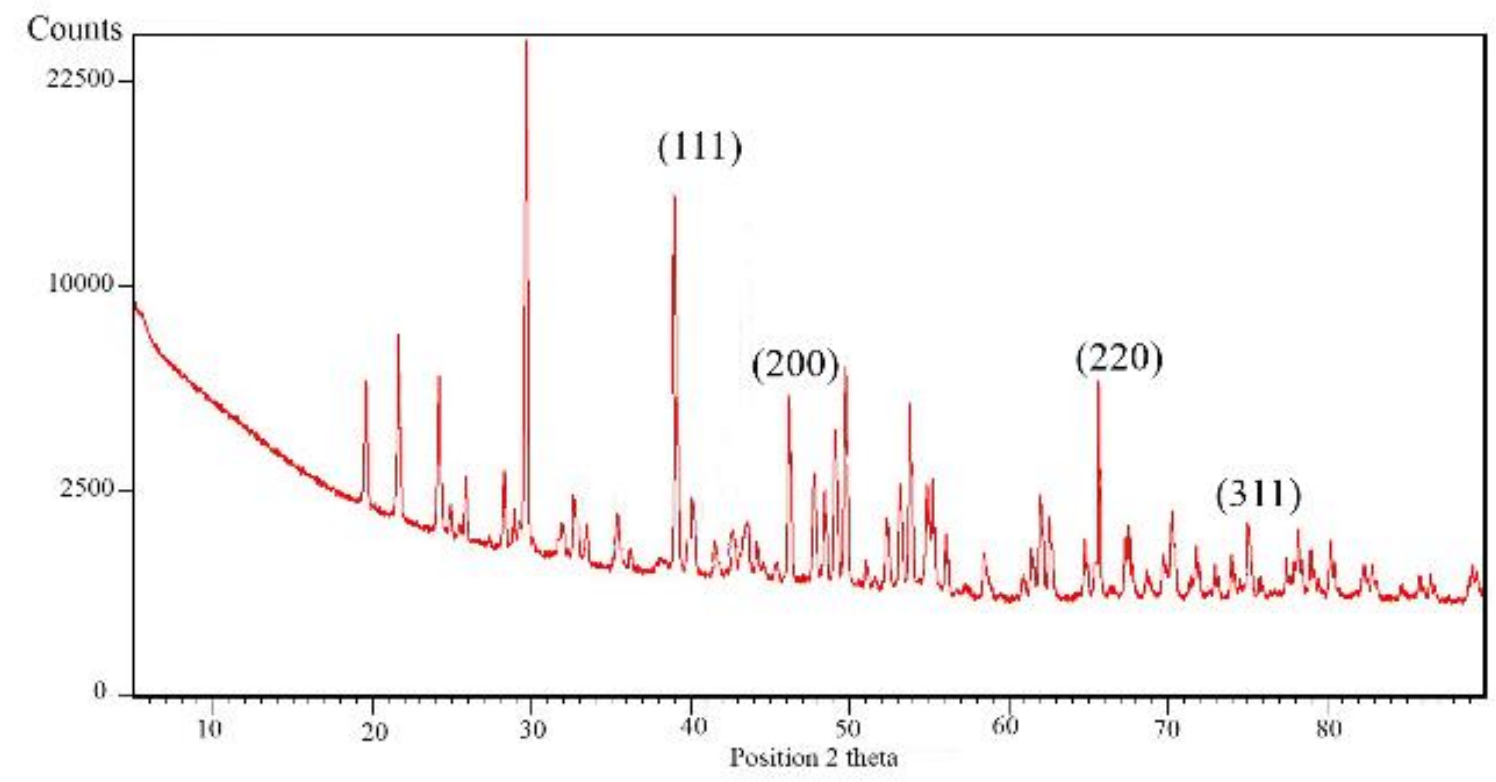

Figure 4. X-ray diffraction patterns of Ma-Ag-NPs
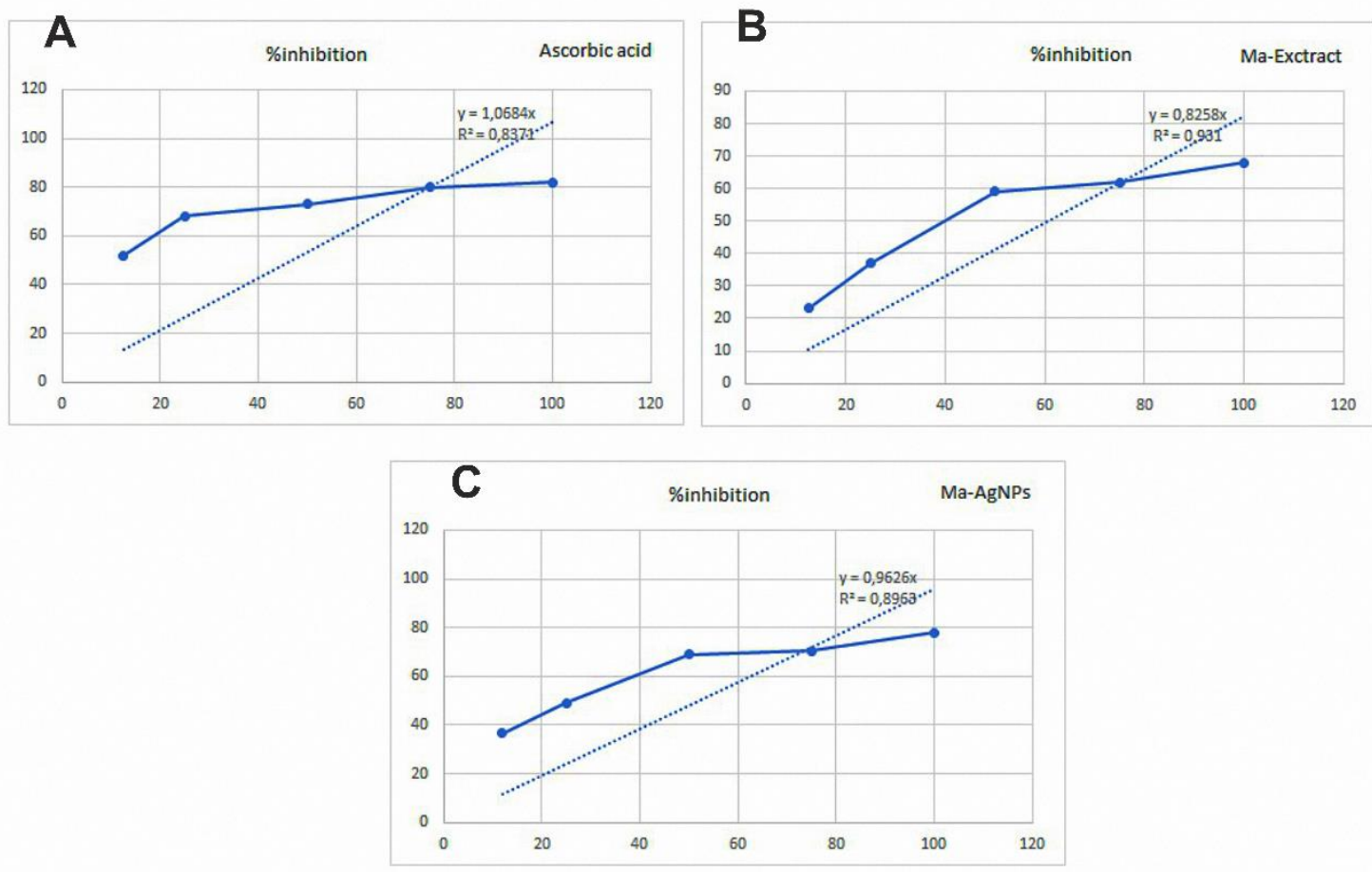

Figure 5. Concentration response curve for ascorbic acid, Ma-Extract and Ma-AgNP at $517 \mathrm{~nm}$ 


\section{Antioxidant activity}

The antioxidant potential of $M$. autumnalis root juice extract was compared with the known antioxidant ascorbic acid, and its free radical scavenging ability was evaluated Figure 5 images a decrease in DPPH radical due to the removal of Ma-AgNPs, Ma-Ecxtract and Ascorbic acid.

\section{Antimicrobial activity}

Results of antibacterial activity of Ma-Extract and Ma-Ag NP are presented in Table 2. According to our results, It has been stated that Ma-Ectract and Ma-AgNPs at $25 \mu \mathrm{g} / \mathrm{ml}$ concentration have antibacterial activity against all tested bacterial strains.

Table 1. DPPH radical scavenging potential

\begin{tabular}{|c|c|c|c|c|c|c|c|}
\hline & Concent. & $12.5 \mu \mathrm{g} / \mathrm{ml}$ & $25 \mu \mathrm{g} / \mathrm{ml}$ & $50 \mu \mathrm{g} / \mathrm{ml}$ & $75 \mu \mathrm{g} / \mathrm{ml}$ & $100 \mu \mathrm{g} / \mathrm{ml}$ & IC50 value \\
\hline Ma-AgNPs & \multirow{3}{*}{$\%$ of inhibition } & $35.74 \pm 0,75$ & $48.37 \pm 0,64$ & $67.61 \pm 1,17$ & $71.40 \pm 1,04$ & $78.93 \pm 0,98$ & $51.81 \pm 0,10$ \\
\hline Ma-Exct. & & $23.05 \pm 0,35$ & $37.00 \pm 0,46$ & $59.56 \pm 0.06$ & $62.14 \pm 0,44$ & $68.45 \pm 0,38$ & $47.16 \pm 0,41$ \\
\hline Asc. acid & & $52.45 \pm 0,23$ & $68.81 \pm 0,41$ & $73.36 \pm 0.18$ & $80.67 \pm 0,34$ & $82.47 \pm 0,43$ & $46.85 \pm 0,39$ \\
\hline
\end{tabular}

Green synthesis of nano-sized particles using biological agents and biosynthesis of various nanoparticle forms such as copper, iron, platinum, silver and zinc has been an important approach. In this study, green synthesis of silver nanoparticles (AgNPs) was carried out with aqueous root extract of M. autumnalis. Silver nitrate incubated with

Table 2. Inhibition zone diameters of biosynthesized silver nanoparticles (Ma-AgNPs) evaluated by disk diffusion method $(\mathrm{mm})$

\begin{tabular}{lllll}
\hline \multicolumn{5}{c}{ Gram positive } \\
& B. subtilis & S. aureus & E. coli & P. aeruginosa \\
\hline Ma-AgNPs & 4.2 & 5.5 & 6.4 & 6.8 \\
\hline Ma-Extract & 6.3 & 3.1 & 3.8 & 4.3 \\
\hline Antibiotic & 5.7 & 5.7 & 7.9 & 5.3 \\
\hline
\end{tabular}

aqueous root extract of $M$. autumnalis, a color change from gray to dark brownish was observed within 30 minutes. In the previous literature, it has been noted that the brownish-yellow color transformation after the treatment of plant extract and $\mathrm{AgNO}_{3}$ is a clear indicator of the formation of AgNPs. (Ahmad et al. 2003). Also, the color change can be attributed to the stimulation of surface plasmon vibrations in the nanoparticles and the reduction of silver ions with the plant extract. (Rasheed et al. 2017). In many studies, phytochemical analysis of $M$. autumnalis has been carried out and it has been noted that leaves and roots extracts contain high amounts of phenolic compounds such as tannins, flavonoids, steroids and saponins (Jodallah, 2013). However, it also contains scopolamine alkaloids. Silver nitrate and the photochemical 
content of $M$. autumnalis may play a role in reducing $\mathrm{AgNO}_{3}$ ions to NPs. Vivek et al. (2012) reported that plant components such as glycosides, proteins, carbohydrates, flavonoids, phytosterols, saponins, alkaloids, phenolic compounds, tannins and amino acids are involved in the reduction of silver ions in silver nitrate. (Vivek et al. 2012). In our study, it indicated silver nanoparticle accumulation within thirty minutes of reaction initiation time by UV-vis analysis. Characteristically, the synthesized silver nanoparticles demonstrated an absorption peak around $435 \mathrm{~nm}$. In one study, they reported a UV-vis spectral profile comparable to silver nanoparticles developed from Acorous calamus rhizome extract showing a wider peak around $400 \mathrm{~nm}$ (Nakkala et al. 2014). Similarly, there are some other reports confirming that the resonance peak of AgNPs appears around this region (Thatoi et al. 2016). The morphology of Ma-AgNPs analyzed by SEM image proved different sizes and shapes of silver nanoparticles with an average particle size of 20-30 $\mathrm{nm}$. In addition, these images indicated that most $M a$ AgNPs were round in shape and multiple dispersed. In order to further verify the surface morphology, Ma-AgNPs were also characterized by TEM and Ma-AgNPs were also seen in spherical form with TEM photographs and it was seen that nanaoparticles had a uniform form according to these micrographs. Antioxidant is the general name of the group of compounds that stops or slows down oxidation reactions caused by free radicals (Rice-Evans et al. 1996; Karaman et al. 2009). In recent years, the function and importance of antioxidants have been better understood (Sellappan et al. 2002; Huang et al. 2005). The determination of the total amount of phenolic substances in the plant content is important in terms of giving an idea about the hydroxyl groups that provide antioxidant activity. Therefore there is a very good linear correlation between total phenol content and antioxidant activity (Huang et al. 2005). However, plants contain specific metabolites that enable a large number of activities to take place. It is well known and reported that plant mediated nanoparticle synthesis with these metabolites involves sequential reduction followed by capping of the plant with these components. (Khalil et al. 2010). Previous studies have demonstrated the direct role of phyto-components, especially phenolic compound and flavonoid in free radical scavenging, additionally existence of diverse other phytochemicals, including terpenoids carbohydrates, tannins, saponins, and carbohydrates (Dhar et al. 2012). For this reason, in our study, M. autumnalis plant, which is known to have high phenolic content, was selected for nanoparticle synthesis and its antioxidant activity was determined. There are numerous studies on various medicinal plants in synthesizing silver by green synthesis, but there are no reports on nanoparticle synthesis in $M$. autumnalis. Therefore, this study investigated the potential of M. autumnalis mediated AgNP for antioxidant activity. Antioxidant activities of $M$. autamnalis aqueous root extracts and nanoparticles synthesized from it were evaluated using in vitro DPPH test system. $M$. autamnalis has a very high phenolic content, making it one of the large groups of compounds that act as basic antioxidant or free radical terminator. The antioxidant activity of phenolic compounds is ascribed to their ability to donate hydrogen atoms to free radicals (Zin et al. 2006). They also have structural properties that allow free radical scavengers to act as possible antioxidants (Jayathilakan et al. 2007; Norshazila et al. 2010). DPPH is a helpful reagent specifically for investigating the free radical scavenging activity of phenolic compounds and is a substrate for evaluating the antioxidant activity of various antioxidants (Duh et al. 1999). The reduced DPPH absorption is an indication of the extracts' capacity to scavenge free radicals independent of any enzymatic activity. The results of the DPPH test are expressed as the IC50 
value defined as the amount of antioxidant required to reduce the first DPPH concentration by 50\% (Deng et al. 2011; Scherer and Godoy, 2009). In this study, our results are presented by giving the LC50 value. In addition, since DPPH, antioxidant analysis results are very sensitive to variables such as DPPH concentration, standard substance concentration, light, oxygen, humidity, $\mathrm{pH}$ and reaction / incubation time, repetitions were performed at the same time and the incubation time was determined as 30 minutes. Accordingly, the ability of the Ma-AgNPs and the Ma-extract to reduce DPPH was evaluated by observing the color change (no color change was observed in the control). The freshly prepared DPPH solution exhibited a dark purple color at $517 \mathrm{~nm}$, which is its maximum absorbance. The removal of the purple color with the addition of Ma-AgNPs may be due to the presence of antioxidants in the environment. When Ma-AgNPs synthesized using the green method and Ma-Extract are compared with the standard antioxidant ascorbic acid, Ma-AgNPs showed effective inhibitory activity, ie it was found to be strong free radical scavengers. The results obtained are summarized in Table 1. The scavenging ability of Ma-AgNPs and Ma-Extract increased in a dose-dependent manner. The scavenging ability recorded for the lowest concentration of Ma-AgNPs $(12.5 \mu \mathrm{g} / \mathrm{ml})$ was $35.71 \pm 0.05$ and when the concentration reached $100 \mu \mathrm{g} / \mathrm{ml}$ (mean IC50) this scavenging ability was $78.93 \pm$ 0.98 has risen. However, cleaning ability was noted for Ma-Extract at the lowest concentration of $23.05 \pm 0.35(12.5 \mu \mathrm{g} / \mathrm{ml})$, and when the concentration was increased, the cleaning ability was $47.16 \pm 0.41$ with an average IC50 value (Table 1). When we look at all these results, it was seen that Ma-AgNPs have more antioxidant activity than Ma-extract and ascorbic acid. It has already been noted that Ma-extract is even higher in antioxidant than ascorbic acid used as standard. The results of other studies carried out also confirm our study. Antioxidant activity of silver nanoparticles synthesized from Elephantopus scaber leaf extract was evaluated by DPPH analysis and they reported that the photosynthesized silver nanoparticle also has antioxidant potential Kharat and Mendhulkar (2016). They suggested that photosynthesized NPs could be used as a potential free radical scavenger. Another study examined the in vitro antioxidant activity of nanoparticles biosynthesized from Pongamia pinnata extract and found significant free radical scavenging potential (Priya et al. 2016). Another study indicated the presence of strong antioxidant activity in terms of DPPH radical scavenging (IC50 $385.87 \mu \mathrm{g} / \mathrm{mL}$ ) of silver nanoparticles (AgNP) synthesized using an aqueous extract of corn (Zea mays L.), the waste material of the crop, as both a reducing agent and a stabilizer / capping agent. (Patra and Baek, 2016). Biosynthesized nanoparticles (AgNPs) using aqueous leaf extract of Erythrina suberosa (Roxb.), their antioxidant properties were examined by radical scavenging (DPPH) analysis and suggested its application as a potential antimicrobial agent (Mohanta et al. 2017). In our study with $M$. autumnalis, silver nanoparticles obtained by green synthesis were found to have high antioxidant properties. Many types of antibacterial agents are used in various industries. One of the most studied are Ag ions and their inorganic forms. However, these chemical antibacterial agents are limited by multidrug resistance. Therefore, attention has turned to alternative ways to overcome these problems; Therefore, detailed investigation of AgNPs synthesized from $M$. autumnalis by green synthesis method has revealed the fact. Antibacterial activity was performed to reveal the biomedical application of Ma-AgNPs synthesized from M. autumnalis aqueous root extract as an antibacterial agent, and the results are indicate in Table 2. Ma-AgNPs indicated much antibacterial activity compared to Ma-Extract. All bacteria tested were found to differ from each other in terms of their structure and sensitivity to Ma-AgNPs. Among all 
the bacteria tested, $P$. aeruginosa bacteria were found to be more sensitive to AgNPs. The resistant antibacterial activity of Ma-AgNPs compared to Ma-Extract may be due to their small size, large surface area, and surface-adhering biomolecules in Ma-AgNPs.

\section{Conclusion}

We successfully synthesized AgNPs from the aqueous root extract of M. autumnalis as an environmentally friendly, cost-effective and non-toxic method. Ma-AgNPs were visualized with SEM and TEM as they are round in shape and very small in size. Due to the uncontrolled use of some antibiotics, the invasion and spread of different resistant bacterial strains is increasing day by day. In this setting, the apparent antibacterial potential of silver nanoparticles can be valuable in the development of antibacterial drugs against pathogenic strains. Ma-AgNPs showed good results when considered as an alternative antibacterial and antioxidant agent. Silver nanoparticles obtained using a wide range of $M$. autumnalis as bioactive compounds can make them the ideal agent to control infectious agents and give their roles in other pharmaceutical fields.

\section{Acknowledgements}

A special thanks to my father Murat Özkan for his exertion. May his soul rest in peace.

\section{References}

Ahmad, A., Mukherjee, P., Senapati, S., Mandal, D., Khan, M. I., Kumar, R. \& Sastry, M. 2003. "Extracellular biosynthesis of silver nanoparticles using the fungus Fusarium oxysporum". Colloids and surfaces B: Biointerfaces, 28(4), 313-318.

Alam, M. N., Roy, N., Mandal, D. \& Begum, N. A. 2013. "Green chemistry for nanochemistry: exploring medicinal plants for the biogenic synthesis of metal NPs with fine-tuned properties". Rsc Advances, 3(30), 11935-11956.

Annamalai, A., Christina, V. L. P., Sudha, D., Kalpana, M., Lakshmi, P. T. V. 2013. "Green synthesis, characterization and antimicrobial activity of Au NPs using Euphorbia hirta L. leaf extract”. Colloids and Surfaces B: Biointerfaces, 108, 60-65.

Bindhani, B. K., Panigrahi, A. K. 2015. "Biosynthesis and characterization of silver nanoparticles (SNPs) by using leaf extracts of Ocimum Sanctum L (Tulsi) and study of its antibacterial activities". J. Nanomed. Nanotechnol, 1, S6.

Brand-Williams, W., Cuvelier, M. E., Berset, C. L. W. T. 1995. "Use of a free radical method to evaluate antioxidant activity". LWT-Food Science and Technology, 28(1), 25-30.

Dağlığlu, Y., \& Yılmaz Öztürk, B. 2016. "The assessment of biological accumulation on exposure in boron particles of Desmodesmus multivariabilis". Biological Diversity and Conservation, 9(3), 204-209.

Dağlığlu, Y., \& Türkiş, S. 2017a. “Myriophyllum spicatum'un süperoksit dismutaz enzim aktivitesi, lipid peroksidasyonu ve hidrojen peroksit üzerine nano ve mikro bor partiküllerinin etkisi “. Bitlis Eren Üniversitesi Fen Bilimleri Dergisi, 6(2), 62-70. 
Dağlığlu, Y., \& Türkiş, S. 2017a 2017b. Effect of TiO2 nanoparticles application on photosynthetic pigment contents of duckweed (Lemna minor L.).Acta Biologica Turcica, 30(4), 108-115.

Dağlığlu, Y. 2018. "The comparatıve toxicity of nano and micro boron particles to freshwater microalga (Desmodesmus multivariabilis): the importance of particles size ". Fresenius Environmental Bulletin, 27(12 B), 9602-9610.

Dağlığlu, Y., Öztürk, B. Y. 2019. “A novel intracellular synthesis of silver nanoparticles using Desmodesmus sp. (Scenedesmaceae): different methods of pigment change". Rendiconti Lincei. Scienze Fisiche e Naturali, 30(3), 611-621.

Deng, J., Cheng, W., \& Yang, G. 2011. "A novel antioxidant activity index (AAU) for natural products using the DPPH assay". Food Chemistry, 125(4), 1430-1435.

Dhar, P., Tayade, A. B., Saurav, S. K. \& Chaurasia, O. P., Srivastava, R. B. \& Singh, S. B. 2012. "Antioxidant capacities and phytochemical composition of Hippophae rhamnoides L. leaves methanol and aqueous extracts from trans-Himalaya". Journal of Medicinal Plants Research, 6(47), 5780-5788.

Duh, P. D., Tu, Y. Y., \& Yen, G. C. 1999. "Antioxidant activity of water extract of Harng Jyur (Chrysanthemum morifolium Ramat)". LWT-Food Science and Technology, 32(5), 269-277.

Francis, B. 2008. "Between Medicine, Magic, and Religion: Wonder Drugs in German Medico Pharmaceutical Treatises of the thirteenth to Sixteenth Centuries". Speculum, 83(1), 1-57.

Gursoy, N., Ozturk, B. Y. \& Dag, I. 2021. "Synthesis of intracellular and extracellular gold nanoparticles with a green machine and its antifungal activity". Turkish Journal of Biology, 45(2), 196-213.

Huang, D., Ou, B. \& Prior, R. L. 2005. "The chemistry behind antioxidant capacity assays". Journal of agricultural and food chemistry, 53(6), 1841-1856.

Jana, S. \& Pal, T. 2007. "Synthesis, characterization and catalytic application of silver nanoshell coated functionalized polystyrene beads". Journal of nanoscience and nanotechnology, 7(6), 2151-2156.

Jayarambabu, N., Akshaykranth, A., Rao, T. V., Rao, K. V. \& Kumar, R. R. 2020. "Green synthesis of $\mathrm{Cu}$ nanoparticles using Curcuma longa extract and their application in antimicrobial activity". Materials Letters, 259, 126813.

Jayathilakan, K., Sharma, G. K., Radhakrishna, K., \& Bawa, A. S. 2007.“Antioxidant potential of synthetic and natural antioxidants and its effect on warmed-over-flavour in different species of meat". Food Chemistry, 105(3), 908-916.

Jodallah, N. B. E. 2013. Antioxidant and antimicrobial activity of Mandragora autumnalis Bertol extracts. Doctoral dissertation. An-Najah National University, Nablus, Palestine.

Kanipandian, N., Kannan, S., Ramesh, R., Subramanian, P. \& Thirumurugan, R. 2014. "Characterization, antioxidant and cytotoxicity evaluation of green synthesized silver nanoparticles using Cleistanthus collinus extract as surface modifier". Materials Research Bulletin, 49, 494-502. 
Karaman, S., , Tütem E, Başkan, K. S., Apak R. 2009. "Comparison of total antioxidant capacity and phenolic composition of some apple juices with combined HPLC-CUPRAC assay". Food Chemistry 120:1201-1209.

Khalil, M. M., Ismail, E. H., \& El-Magdoub, F. 2012. "Biosynthesis of Au nanoparticles using olive leaf extract: 1st nano updates". Arabian Journal of Chemistry, 5(4), 431-437.

Kharat, S. N. \& Mendhulkar, V. D. 2016. "Synthesis, characterization and studies on antioxidant activity of silver nanoparticles using Elephantopus scaber leaf extract". Mater. Sci. Eng. C, 62, 719-724.

Mahmoodi, N. O., Jalalifard, Z. \& Fathanbari, G. P. 2020. "Green synthesis of bis-coumarin derivatives using $\mathrm{Fe}$ (SD) 3 as a catalyst and investigation of their biological activities". Journal of the Chinese Chemical Society, 67(1), 172-182.

Mehmood, A., Murtaza, G., Bhatti, T. M., \& Kausar, R. 2014. "Enviro-friendly synthesis of silver nanoparticles using Berberis lycium leaf extract and their antibacterial efficacy". Acta Metallurgica Sinica (English Letters), 27(1), 75-80.

Mohanta, Y. K., Panda, S. K., Jayabalan, R., Sharma, N., Bastia, A. K. \& Mohanta, T. K. 2017. "Antimicrobial, antioxidant and cytotoxic activity of silver nanoparticles synthesized by leaf extract of Erythrina suberosa (Roxb.)". Frontiers in molecular biosciences, 4, 14.

Muthukrishnan, S., Bhakya, S., Kumar, T. S., \& Rao, M. V. 2015. "Biosynthesis, characterization and antibacterial effect of plant-mediated silver nanoparticles using Ceropegia thwaitesii-An endemic species". Industrial crops and products, 63, 119-124.

Nakkala, J. R., Mata, R., Gupta, A. K. \& Sadras, S. R. 2014. "Biological activities of green silver nanoparticles synthesized with Acorous calamus rhizome extract". European journal of medicinal chemistry, 85, 784-794.

Nidhin, M., Indumathy, R., Sreeram, K. J. \& Nair, B. U. 2008. "Synthesis of iron oxide nanoparticles of narrow size distribution on polysaccharide templates". Bulletin of Materials Science, 31, 93- 96.

Norshazila, S., Syed Zahir, I., Mustapha Suleiman, K., Aisyah, M. R., \& Kamarul Rahim, K. 2010. "Antioxidant levels and activities of selected seeds of malaysian tropical fruits". Malaysian Journal of Nutrition, 16(1).

Öztürk, B. Y. \& Öztürk, D. 2019. "Single Cell Level Microalgal green synthesis of silver nanoparticles: Confocal Microscopy and Digital Image Analysis". Eurasian Journal of Biological and Chemical Sciences, 2(2), 56-60.

Öztürk, B. Y. \& Öztürk, D. 2020. Tilia rubra DC. ekstraktı kullanılarak gümüş nanopartikülün hücre dişı biyosentezi ve antifungal aktivitesi ". Biyolojik Çeşitlilik ve Koruma, 13(3), 244-251.

Öztürk, B. Y., Gürsu, B. Y., \& Dağ, İ. (2020). “Antibiofilm and antimicrobial activities of green synthesized silver nanoparticles using marine red algae Gelidium corneum". Process Biochemistry, 89, 208-219. 
Özturk, Y.B., \& Daglioglu, Y. 2021. "Extracellular synthesis of slver nanoparticles using Cladophora sp. and its antimicrobial activity effects on lipid peroxidation and antioxidant activites of extracts. Fresenıus Environmental Bulletin, 30(06B),7422-7432.

Patra, J. K. \& Baek, K. H. 2016. "Biosynthesis of silver nanoparticles using aqueous extract of silky hairs of corn and investigation of its antibacterial and anticandidal synergistic activity and antioxidant potential". IET Nanobiotechnol., 10, 326-333.

Priya, R. S., Geetha, D. \& Ramesh, P. S. 2016. "Antioxidant activity of chemically synthesized AgNPs and biosynthesized Pongamia pinnata leaf extract mediated AgNPs - A comparative study". Ecotoxicol. Environ., 134, 308-318.

Rai, M. K., Deshmukh, S. D., Ingle, A. P. \& Gade, A. K. 2012. "Silver nanoparticles: the powerful nanoweapon against multidrug-resistant bacteria". Journal of applied microbiology, 112(5), 841-852.

Rasheed, T., Bilal, M., Iqbal, H. M. \& Li, C. 2017. "Green biosynthesis of silver nanoparticles using leaves extract of Artemisia vulgaris and their potential biomedical applications". Colloids and Surfaces B: Biointerfaces, 158, 408-415.

Rice-Evans, C. A., Miller, N. J., Paganga, G. 1996. "Structure-antioxidant activity relationships of flavonoids and phenolic acids". Free Radical Biology Medicine 20:933-956.

Rónavári, A., Kovács, D., Igaz, N., Vágvölgyi, C., Boros, I. M., Kónya, Z., Pfeiffer, I. \& Kiricsi, M. 2017. Biological activity of green-synthesized silver nanoparticles depends on the applied natural extracts: a comprehensive study, International journal of nanomedicine, 12, 871.

Sands, D. E. 1993. Introduction to crystallography. Courier Corporation. Dover Publications, Inc, Mineola, Newyork.

Saratale, G. D., Saratale, R. G., Benelli, G., Kumar, G., Pugazhendhi, A., Kim, \& D. S.

Shin, H. S. 2017. "Anti-diabetic potential of silver nanoparticles synthesized with Argyreia nervosa leaf extract high synergistic antibacterial activity with standard antibiotics against food borne bacteria”. Journal of Cluster Science, 28(3), 1709-1727.

Scherer, R. \& Godoy, H. T. 2009. "Antioxidant activity index (AAI) by the 2, 2-diphenyl-1picrylhydrazyl method”. Food chemistry, 112(3), 654-658.

Sellappan, S., Akoh, C. C. \& Krewer, G. (2002). "Phenolic compounds and antioxidant capacity of Georgia-grown blueberries and blackberries". Journal of agricultural and food chemistry, 50(8), 2432-2438.

Thatoi, P., Kerry, R. G., Gouda, S., Das, G., Pramanik, K., Thatoi, H. \& Patra, J. K. 2016. "Photo-mediated green synthesis of silver and zinc oxide nanoparticles using aqueous extracts of two mangrove plant species, Heritiera fomes and Sonneratia apetala and investigation of their biomedical applications". Journal of Photochemistry and Photobiology B: Biology, 163, 311-318.

Vivek, R., Thangam, R., Muthuchelian, K., Gunasekaran, P., Kaveri, K. \& Kannan, S. 2012. "Green biosynthesis of silver nanoparticles from Annona squamosa leaf extract and its in vitro cytotoxic effect on MCF-7 cells". Process Biochemistry, 47(12), 2405-2410. 
Wang, X. P., Yu, Y., Hu, X. F. \& Gao, L. 2000. "Hydrophilicity of $\mathrm{TiO}_{2}$ films prepared by liquid phase deposition”. Thin Solid Films, 371(1-2), 148-152.

Yılmaz Öztürk, B., Dağlığlu, Y., Aşıkkutlu, B., \& akköz, C. 2018. "Changes in pigment content of green algae (Desmodesmus sp. and Chodatodesmus mucranulatus) exposed to alumina oxide (A12O3) nanoparticles“. Biological Diversity and Conservation, 11(3), 64-70.

Yousaf, H., Mehmood, A., Ahmad, K. S., \& Raffi, M. 2020. "Green synthesis of silver nanoparticles and their applications as an alternative antibacterial and antioxidant agents". Materials Science and Engineering: C, 112, 110901.

Zin, Z. M., Hamid, A. A., Osman, A., \& Saari, N. 2006. "Antioxidative activities of chromatographic fractions obtained from root, fruit and leaf of Mengkudu (Morinda citrifolia L.)". Food Chemistry, 94(2), 169-178. 